\title{
Evaluation of Some Blood Cells and Metabolites of Heterobranchus bidorsalis (Hybrid) Exposed to Sublethal Concentrations of Sarosate
}

\author{
Inyang, I.R., Akparanta, O.J.and Izah, S.C*. \\ Ecotoxicology Research Unit, Department of Biological Sciences, Faculty of Science, Niger Delta University, \\ Wilberforce Island, Bayelsa State, Nigeria.
}

\author{
*Corresponding Author: Izah S.C. Department of Biological Sciences, Faculty of Science, Niger Delta \\ University, Wilberforce Island, Bayelsa State, Nigeria
}

\begin{abstract}
Sarosate induced changes on some blood cells and metabolites activity of Heterobranchus bidorsalis (hybrid), a common Niger Delta wetland fish were assessed. Adult fish (mean length, 15.07 $\pm 0.29 \mathrm{~cm}$ ) were acclimatized to laboratory conditions for nine days and then exposed to varying sublethal concentration of sarosate (1.00, 2.00 and 3.00gl-1) in a semi static bioassay for 32 days. All the parameters were determined in the plasma. Some blood cells (red blood cells $(R B C)$, white blood cells (WBC), platelets) values were significant ( $p<0.05)$ almost in a dose dependent pattern. RBC values increased as the concentration of sarosate increases, TWBC only showed a significant value at the last concentration, compared to control. Platelets values observed were not concentration-dependent pattern. Bilirubin values at the last concentration were statistically significant. Albumin values fluctuate within the experimental group. A slightly retrogressive value was observed in platelets, akin to haemoglobin at 1.00 and $2.00 \mathrm{gl}-1$. It is concluded that sarosate at high concentration could be toxic to Heterobranchus bidorsalis. The use of sarosate in the aquatic environment should be done with caution. Additionally, Blood cells and metabolites parameters used in this research may serve as useful biomarkers of sublethal effect of sarosate on Heterobranchus bidorsalis.
\end{abstract}

Keywords: Blood cells, Heterobranchus bidorsalis, glyphosate, metabolites

\section{INTRODUCTION}

Anthropogenic releases and naturally occurring substances released into the aquatic environment are capable of altering the water quality as well as posing as a threat to aquatic biota. Pollution via pesticides has dominated discussion globally because of xenobiotics distortion of aquatic ecosystem and potential effect on man via food chain. According to Semante et al. (2014), pesticide contamination in the aquatic ecosystem has gained much attention all over the word as they are posing serious threat to aquatic organisms especially non-target organisms (fin fish and shell fish), which are exposed to a large amount of pesticides persistently as a consequence of rapid industrialization, agricultural practices and anthropogenic releases.

Herbicides (crop protecting chemicals) are considered as one of the most prevalent agonist in the aquatic ecosystem due to their effect on non target organisms. Sarosate (glyphosate based herbicide, containing $480 \mathrm{~g} / \mathrm{l}$ in form of isopropyl amine salt) is one of the most prevalent herbicide in the Niger Delta States of Nigeria, used mainly for weed control.

Glyphosate (N-phosphomethy-glycine) is a post-emergent herbicide widely used in several types of cultures (Modesto and Maninez, 2010). Numerous commercial formulations containing glysophate as the active ingredient have become popular around the word due to their effective action and low toxicity to mammals (Corbera et al., 2005). Glyphosate act by inhibiting amino acid synthesis necessary for growth and development of weeds, crops and plants as well as aquatic organisms such as fish (Kumar et al., 2007).

Surfactants are critical part of an herbicide formation as it assists adhesion to wetting and spreading on leaf and uptake through the leaf (Modesto and Matinez, 2010). Some surfactants that are included in some formulations of glysophate however are highly toxic to aquatic organisms and these formulations are not registered for aquatic use (Tu et al., 2001). 
Heterobranchus bidorsalis, popularly known as African Catfish, is an air breathing catfish found in Africa (Oyokoro and Ogamba, 2017). Several species of Clarias gariepinus, Heteroclarias and Heterobranchus bidorsalis are prevalent in the Niger Delta states of Nigeria. Heterobranchus bidorsalis is commercially available for human consumption. Studies have shown that it is tolerant to acute level of detergents (xenobiotics) but not as comparable to Clarias gariepinus (Oyokoro and Ogamba, 2017). Effect of these toxicants on aquatic organisms is a very serious environmental factor since this effect can easily move to higher organisms (e.g man) via food chain.

Studies have shown that not all applied pesticides may actually reach targeted pests and the remaining have potential to get into the soil, water and the atmosphere (Don et al., 2002; Goodman et al., 2006). Humans and animals are occasionally and unintentionally exposed to lethal and sublethal doses of pesticides (Eddleston, 2000; Martin et al., 2003). According to Chindah et al.(2000), the presence of these pesticides in the aquatic ecosystem through the process of nutrition (food) can lead to bioaccumulation in fish and biomagnification in humans, hence the need to study the effect of these xenobiotics on aquatic organisms. Additionally, after exposure to pollutant, fish may exhibit alterations in metabolism and behavioural responses. According to Ajani and Awogbade (2012), several studies indicated that after exposure to a pesticide, fish may exhibit an increase or decrease in levels of serum protein, cortisol, glucose, cholesterol, ions and in the activities of serum enzymes. Some of these indices can be used as indicators of exposure of xenobiotics to fish.

A biomarker may be any measurable biochemical, cellular, physiological or behavioural change in an organism or population that indicates exposure to chemical pollutants (Depedge, 1994). Focusing on the immediate, sublethal effects of a pollutant, this developing field aims to reveal environmental threats before obvious toxic effects such as death of organisms are observed (Alyand El-Gendy, 2014).

Therefore, the essence of this research was to unveil the effect of the commonly used herbicide (Sarosate) on some Heterobranchus bidorsalis blood cells and metabolites.

\section{MATERIALS AND MethodS}

\subsection{Fish Procurement}

Fish samples (juveniles of Heterobranchus bidorsalis) precisely, 30 in number were obtained from biotechnology research center, Odi, Bayelsa State, Nigeria. They were transported to the wet Laboratory, Department of Fisheries, Faculty of Agricultural Technology, Niger Delta University, were the assay were conducted between November, 2015 and January, 2016.

Heterobranchus bidorsalis (hybrid), mean weight $98.05 \pm 0.4 \mathrm{SD}$ and mean length, $15.07 \pm 0.29 \mathrm{cmSD}$ were acclimatized in a rectangular aquaria for nine days during which they were fed once a day (10.0011.00 hours) with $35 \%$ crude protein at $1 \%$ biomass. Sublethal concentration of sarosate (containing $480 \mathrm{~g} / \mathrm{l}$ ) was determined based on the range finding test. The definitive test (main test) was carried out by pipetting $0.06 \mathrm{mls}, 0.13 \mathrm{mls}$, and $0.19 \mathrm{mls}$ respectively from the original solution and making it up to 30 litres borehole water in the aquaria to make $1.00 \mathrm{ppm}, 2.00 \mathrm{ppm}$ and $3.00 \mathrm{ppm}$ i.e the concentration used. There were four treatment levels with four replicates. The experimental solution was renewed every 24 hours and the experiment lasted for 32 days.

The physico-chemical characterization of the water used for fish bioassay was carried out using standard methods (APHA, 1998) and the following values were obtained; $\mathrm{pH} 5.55-6.30$, temperature $23^{\circ} \mathrm{C}-$ $24^{\circ} \mathrm{C}$, dissolved oxygen $4.36-7.24 \mathrm{mgl}^{-1}$, alkalinity $9.22-14.07 \mathrm{mgl}^{-1}$, conductivity $94.49-130.00 \mu \mathrm{scm}^{-}$ ${ }^{1}$ and turbidity $0.15-0.48 \mathrm{NTU}$.

Blood samples for haematological and metabolic analysis were collected from each fish (behind the anal fin) with $23 \mathrm{G}$ size needle and syringe. Fish were not fed prior to blood collection. Standard haematological procedures unveiled by Blaxhall and Daislay (1973) were used in the determination of haematological parameters. Values of oxygen carrying capacity (OCC) were calculated using the formular:

$$
\text { OCC }=\text { Haemoglobin Content } \mathrm{x} 1.25 \text { (Inyang, 2008) }
$$

Plasma metabolites were determined according to Bergmeyer et al. (1986) methods.

\subsection{Statistical Analysis}

The data were subjected to analysis of variance (ANOVA) where differences exist, Duncan multiple range test $(\mathrm{DMRT})$ were used to test for pairwise significant difference $(\mathrm{p}<0.05)$ between treatments (Wahua, 1999). 
Evaluation of Some Blood Cells and Metabolites of Heterobranchus bidorsalis (Hybrid) Exposed to Sublethal Concentrations of Sarosate

\section{RESUlTS}

\subsection{Blood Cells}

The red blood values increased slightly as the concentration of sarosate increases, almost in a dose dependent pattern. The highest values were recorded at 2.00 and $13.00 \mathrm{mgl}^{-1}$. The total white blood cells values were irregular, albeit the highest value was recorded at the highest concentration $\left(3.00 \mathrm{mgl}^{-1}\right)$. The values did not indicate any dose dependent pattern. Fluctuations in values were recorded. The highest value was recorded at $1.00 \mathrm{mgl}^{-1}\left(211.25 \pm 2.3 \times 10^{9} / \mathrm{l}\right)$. Platelet values were akin to total white blood cell and haemoglobin. Values fluctuate down the experimental group. The highest value recorded was $74.00 \pm 0.16 \times 10^{9} / 1$ compared to the control that had $25.67 \pm 0.08$ (Table 1). Oxygen carrying capacity values trend along the experimental group was akin to haemoglobin. The highest concentration of the toxicant had the highest value. Values were not significant $(\mathrm{p}>0.05)$.

\subsection{Metabolites}

Total and conjugated bilirubin values were statistically significant $(\mathrm{p}<0.05)$. Total bilirubin values fluctuate within the experimental group. The lowest value was recorded at 1.00 and $3.00 \mathrm{mgl}^{-1}$ compared to control (Table 2). Similar pattern was also observed in conjugated bilirubin, total protein and albumin. Values were statistically significant $(\mathrm{p}<0.05)$. A dose dependent pattern was observed. The values decreased down the experimental group as the concentration increases. Urea values fluctuated down the experimental group. There was no significant difference between the control and the highest concentration $\left(3.00 \mathrm{mgl}^{-1}\right)$, while the first and second concentrations value were also insignificant, albeit the values were slightly higher than the control and the highest concentration $\left(3.00 \mathrm{mgl}^{-1}\right)$

Table1. Blood cells of Heterobranchus bidorsalis (hybrid) exposed to chronic levels of sarosate for 32 days.

\begin{tabular}{|l|l|l|l|l|l|}
\hline $\begin{array}{c}\text { Conc. of } \\
\text { Sarosate } \\
\left(\mathrm{Mgl}^{-1}\right)\end{array}$ & $\begin{array}{c}\text { RBC } \\
\left(\times 10^{12} / \mathrm{L}\right.\end{array}$ & $\begin{array}{c}\text { TWBC } \\
\left(\times 10^{9} / \mathrm{L}\right)\end{array}$ & $\begin{array}{c}\text { Platelets } \\
\left(\mathrm{x} 10^{9} / \mathrm{L}\right)\end{array}$ & $\begin{array}{c}\mathrm{Hb} \\
(\mathrm{g} / \mathrm{dl})\end{array}$ & $\begin{array}{c}\text { OCC } \\
(\mathrm{g} / 100 \mathrm{ml})\end{array}$ \\
\hline 0.00 & $2.47 \pm 0.01^{\mathrm{a}}$ & $219.40 \pm 2.45^{\mathrm{ab}}$ & $25.67 \pm 0.08^{\mathrm{d}}$ & $11.47 \pm 0.03^{\mathrm{a}}$ & $14.34 \pm 0.00^{\mathrm{a}}$ \\
\hline 1.00 & $2.50 \pm 0.01^{\mathrm{a}}$ & $211.25 \pm 2.31^{\mathrm{ab}}$ & $74.00 \pm 0.16^{\mathrm{a}}$ & $9.55 \pm 0.04^{\mathrm{b}}$ & $11.94 \pm 0.03^{\mathrm{ab}}$ \\
\hline 2.00 & $2.65 \pm 0.02^{\mathrm{a}}$ & $213.95 \pm 4.10^{\mathrm{a}}$ & $52.00 \pm 1.41^{\mathrm{b}}$ & $11.30 \pm 0.03^{\mathrm{ab}}$ & $14.13 \pm 0.07^{\mathrm{a}}$ \\
\hline 3.00 & $2.65 \pm 0.10^{\mathrm{a}}$ & $231.00 \pm 3.15^{\mathrm{a}}$ & $46.00 \pm 2.00^{\mathrm{c}}$ & $11.55 \pm 0.01^{\mathrm{a}}$ & $14.44 \pm 0.07^{\mathrm{a}}$ \\
\hline
\end{tabular}

Data is expressed as mean \pm standard deviation $(n=3)$. Different superscript letters within column indicates significant difference $(\mathrm{p}<0.05)$.

Table2. Activities of metabolites in the plasma of Heterobranchus bidorsalis (hybrid) exposed to Sarosate for 32 days

\begin{tabular}{|l|c|c|c|c|c|c|}
\hline $\begin{array}{c}\text { Conc. of } \\
\text { Sarosate } \\
\left(\mathrm{Mgl}^{-1}\right)\end{array}$ & $\begin{array}{c}\text { Total } \\
\text { Bilirubin } \\
\left(\mu \mathrm{mol} \mathrm{l}^{-1}\right)\end{array}$ & $\begin{array}{c}\text { Conjugated } \\
\text { Bilirubin } \\
\left(\mu \mathrm{mol} \mathrm{l}^{-1}\right)\end{array}$ & $\begin{array}{c}\text { Total } \\
\text { Protein } \\
\left(\mathrm{gl}^{-1}\right)\end{array}$ & $\begin{array}{c}\text { Albumin } \\
\left(\mathrm{g} / \mathrm{l}^{-1}\right)\end{array}$ & $\begin{array}{c}\text { Creatinine } \\
\left(\mu \mathrm{mol} \mathrm{l^{-1 }}\right)\end{array}$ & $\begin{array}{c}\text { Urea } \\
\left(\mu \mathrm{mol} \mathrm{l}^{-1}\right)\end{array}$ \\
\hline 0.00 & $3.60 \pm 0.01^{\mathrm{b}}$ & $0.80 \pm 0.00^{\mathrm{c}}$ & $43.00 \pm 0.51^{\mathrm{b}}$ & $13.00 \pm 0.08^{\mathrm{c}}$ & $54.00 \pm 0.13^{\mathrm{a}}$ & $1.30 \pm 0.00^{\mathrm{ab}}$ \\
\hline 1.00 & $7.27 \pm 0.01^{\mathrm{a}}$ & $1.90 \pm 0.03^{\mathrm{b}}$ & $45.67 \pm 0.43^{\mathrm{b}}$ & $15.00 \pm 0.03^{\mathrm{b}}$ & $51.67 \pm 0.12^{\mathrm{ab}}$ & $1.53 \pm 0.01^{\mathrm{a}}$ \\
\hline 2.00 & $2.80 \pm 0.02^{\mathrm{bc}}$ & $1.25 \pm 0.01^{\mathrm{b}}$ & $30.50 \pm 0.09^{\mathrm{c}}$ & $11.00 \pm 0.02^{\mathrm{d}}$ & $44.00 \pm 0.10^{\mathrm{b}}$ & $1.50 \pm 0.00^{\mathrm{a}}$ \\
\hline 3.00 & $6.00 \pm 0.10^{\mathrm{ab}}$ & $4.35 \pm 0.07^{\mathrm{a}}$ & $63.00 \pm 0.14^{\mathrm{a}}$ & $18.50 \pm 0.06^{\mathrm{a}}$ & $43.50 \pm 0.11^{\mathrm{b}}$ & $1.30 \pm 0.01^{\mathrm{ab}}$ \\
\hline
\end{tabular}

Data is expressed as mean \pm standard deviation $(n=3)$. Different superscript letters within the column indicate significant difference $(\mathrm{p}<0.05)$.

\section{DISCUSSION}

\subsection{Haematological Parameters}

Haematological and biochemical profile of blood can provide important information about the internal environment of the organism (Masopust, 2001). Increase or decrease in blood parameters are signs of physiological aberrations in organism and may cause serious health challenges if the trend persists. Significantly, haematological parameters observed in this study indicate a variety of abnormalities as a result of the xenobiotics even at very low concentration of $1.00 \mathrm{mgl}^{-1}$. A slight elevation of values was observed in Red blood cells (RBC) as the concentration of the toxicant increase. The elevation of values of RBC, according to Ojezele and Abatan (2009) may be an indication of a hypotoxic condition. The authors further stated that this might led to a stress-linked release of new erythrocytes and synthesis of International Journal of Research in Environmental Science (IJRES) 
haemoglobin. Health (1995) reported an increase in this parameter. The author opined that this may occur in situation of acute stress, when the adrenergic stimulus triggers splenic contraction, releasing large quantities of RBC into the blood stream. Our result is contrary to the reports unveiled by Inyang (2008), Svodova(2001), Anees (1978). The authors all reported diminutive values as the concentration of the toxicants increased.

The red blood cells are packed with haemoglobin, the organ carrying protein pigment which gives blood its red colour (Tayor et al., 2005). The authors added that haemoglobin combines reversibly with oxygen concentration and releases the oxygen in regions of low concentration. The overt decline in haemoglobin values will lead to series of respiratory problems in cells. A decline in haemoglobin values were observed at the first two concentrations of Sarosate. Decreased haemoglobin has been reported after exposure of fish to toxicants (Adeyemo, 2005; Inyang and Patani, 2015). According to Binukumari and Vasanthi (2013), decline in haemoglobin levels exposed to pesticides such as dimethoate 3\% EC could be attributed to release of immature cells from haemotopoitic tissue into the blood stream as well as disruption of iron metabolism thereby causing defective haemoglobin synthesis.

Platelets (thrombocytes) are disk-shaped cell fragments that function to initiate blood clothing. When a blood vessel is injured, platelets immediately move to site and begin to clump together, attaching themselves to the damaged area, and begin the process of blood coagulation (Miller and Harley, 1994). Elevation in values of platelets in this study may be an offshoot of the effect of Sarosate on certain tissues which led to injuries, hence more production of thrombocytes for repairs.

Insignificant decrease in values of total white blood cells was recorded except at the last concentration, which is not significant ( $p>0.05$ ) compared to control value. This slight decrease in values is contrary to the opinion that since white blood cells function in organisms against foreign bodies aided by phagocytosis and antibody production, values will increase as a result of lethalic effect of the toxicant (Inyang, 2008). Decreased values of haematological parameters have been reported by several authors (Chindah et al., 2004;Adeyemo, 2005;Akaninwor et al., 2006). Inyang and Thomas (2016) also reported decrease in WBC, when they exposed Clarias gariepinus to flauzifop-p-butyl. The authors unveiled that leucocyte decrease is an offshoot of the effect of flauzifop-p-butyl on primitive haematopoitic cells responsible for blood production in fish.Similar results were also reported by Chindah et al. (2000) whey they exposed Tilapia guineensis to chloropyrifos (an organophosphate insecticide). The authors also opined that the agonist (chloropyrifos) affected the fish even as low as $0.1 \mathrm{mgl}^{-1}$. Hontela et al. (1992) opined that this reduction is due to hemodilution resulting impaired osmoregulatory functions of the gill epithelium.

Oxygen carrying capacity recorded at 1.00 and $2.00 \mathrm{mgl}^{-1}$ showed a significant diminution, hence low oxygen carrying capacity. Similar result was also reported by Dhara and Gassert (2004) when they exposed Common Carp (Branchydario rerio) to various concentrations of cyanide. According to the authors, the values of Oxygen carrying capacity decreased with increase in the concentration of the toxicant, again that low oxygen carrying capacity was indicative of some changes in protein haemoglobin and possibly carboxylation (the addition of Carbomyl group, Co- $\mathrm{NH}_{2}$ to a protein of the haemoglobin molecule). Yekeen and Fawole (2011) reported that reduction in the haemoglobin of Clarias gariepinus treated with pesticide (endosulfan) is an indication of decline in haemoglobin synthesis as well as reduction in oxygen carrying capacity resulting from the interference of endosulfan with haemoglobin synthesis pathway.

Bilirubin (conjugated and total) values were significant $(\mathrm{p}<0.05)$ especially at $1.00 \mathrm{mgl}^{-1}$ (total bilirubin) and $3.00 \mathrm{mgl}^{-1}$ (conjugated). Elevation in values of bilirubin has been reported (Inyang, 2008; Jyothi and Narayan,1999). Elevated levels of bilirubin may be attributed to the great damage of hepatocytes, obstruction of the bile duct or a reluctant haemolysis (Ahamed and Gautam, 2014), Okoronkwo et al. (2013) exposed Clarias abopuctatus to roundup and they came to a conclusion that the elevations in serum levels of bilirubin and conjugated bilirubin in a time and dose dependent manner may be subsequent to the disruption of the hepatic architecture by the toxicant such that the conjugation of bilirubin and excretion of bilirubin is altered. Vitek and Ostrow (2009) also unveiled that elevation in serum total and conjugated bilirubin is attributed to liver and biliary tract disease. These opinions seem to be the case in this study. 


\subsection{Albumin and Total Protein}

Plasma protein, which include globulins, fibrinogens and albumins, serve as a vital function in carrying materials from one part of the fish to another via the circulation, they have nutritive transporting, protective, buffering and energetic functions (Cheesbrough, 1992). Values of total protein and albumin accelerate within the experimental group except at $2.00 \mathrm{mgl}^{-1}$. These results are not in consonance with the results of Das and Mukhergee (2000),Jee et al. (2005). They all reported decreased levels of these vital metabolites as the concentration of the toxicant increased.Ovuru (2004) reported elevation of albumin and total protein as a result of exposure of rabbit to hydrocarbon. Similar result was also reported by Inyang et al. (2014) when they exposed Clarias gariepinus to kartodem 315EC. The higher energy demand of the body to counter stress may trigger an increased in protein metabolism, a process in which both blood and structural protein are converted to energy during toxicant induced stress (Das et al., 2004).

Urea and Creatinine are nitrogenous end products of metabolism (Ajeni and Solomon, 2004). Urea is a product of the deamination of glycogenic amino acid in the liver usually under conditions that the system requires energy generation to overcome any physiological stressor (Okonkwo et al., 2013), urea and creatinine have been used as important indices for the evaluation of the effect of xenobiotics on the kidney of vertebrates. Urea and creatinine were not significant $(\mathrm{p}<0.05)$. A slight decrease in values of creatinine was recorded at $3.00 \mathrm{mgl}^{-1}$. Similar result was also reported by Ogamba et al. (2011), when they exposed Clarias gariepinus to paraquat dichloride. The authors recorded decreased urea and creatinine levels as the concentration of the toxicant increased. Decreased levels of urea and creatinine indicate that the kidneys of the probe organism were not affected by the toxicant (Sarosate).

\section{CONCLUSION}

It is concluded that fishes exposed to sarosate unveiled a dose dependent alterations in some haematological indices such as haemoglobin, platelets, total white blood cells and red blood cells akin to some metabolic indices (Total protein and albumin). These alterations exhibited by sarosate is a clear indication of its toxic nature on Heterobranchus bidorsalis (hybrid). The use of this xenobiotics in the aquatic environment should be done with absolute caution, additionally the parameters used are useful biomarkers of sarosate on Heterobranchus bidorsalis (hybrid).

\section{REFERENCES}

[1] Adeyemo, O.K. 2005. Haematological and histopathological effects of cassava mill effluent in Clarias gariepinus. African Journal of Biomedical Research, 6(3): 179 - 183.

[2] Ajani, F. and Awogbade, A.A. 2012. Hematological changes of the African catfish Clarias gariepinus(Burchell, 1822) juveniles induced by Diuron. British Biotech J., 2(4):247-256.

[3] Ajeniyi, S.A and Solomon R.J. 2014. Urea and creatinine of Clarias gariepinus in three different commercial ponds. Nature and Science 12(1): 124-138.

[4] Akaninwor, J.O., Abbay, B.W and Inyang, C.M. 2006.Toxicological effect of crude oil (Bonny light and forcados on Clarias gariepinusand Oreochromis niloticus. Journal of Nigerian Environmental Society, 3(1): $58-64$.

[5] Aly, N. and El-Gendy, K. 2014.Impact of parathion exposure on some biochemical parameters in rabbit as a non target organism. Alex. Journal of Med. 50:11-17.

[6] Anees, M.A. 1978. Haematological abnormalities in a fresh water teleost, Channapunctatus (Bloch), exposed to sublethal and chronic levels of three organophosphate insecticides. Int. J. Ecot. Environ. Sci. (4):53-60.

[7] APHA (American Public health association) 1998. Standard methods for examination of water and waste water, APHA Washington D.C.

[8] Bergmeyer, H.U Horder H and Rej R. 1986.IFFC recommendation. Journal of Clinical Chemistry and Biochemistry, 24: $481-497$.

[9] Binukuman, S, and Vasanthi, J. 2013. Impact of the pesticide dimethoate 30\% EC on the haematological parameters of fresh water fish, Labeorohita IOSR Journal of Environmental Science, Toxicology and Food technology, 7(2):63-65.

[10] Blaxhall, P.C and Daisley, K.W. 1973. Routine haematological methods for use with fish blood. Fish Biology, 5(6):771 - 781.

International Journal of Research in Environmental Science (IJRES)

Page $\mid 21$ 
[11] Cheesbrough, M. 1992. Medical laboratory manual for tropical countries 5 edition.BultleworthHeimannt, Hakkey court Jordan Hill, 472-505.

[12] Chindah, A.C., Sikoki, F.D and Vincent-Akpu, I. 2004.Toxicity of an organophosphate pesticide (Chloropyrifos) on a common Niger Delta Wetland fish, Tilapiaguineensis (Blecker, 1862).J. Appl. Sci. and Env.Managt. 8(2):11-17

[13] Chindah, C.A., Sikoki, F.D and Vincent-Akpu, I,. 2000. Toxicity of cypermethrin to TilapiagunensisJuveniles. J. Agric. Biotech. Environ., 2(1\&2): 60 -66.

[14] Corbera, M., Hidalgo, M., Salvado, V, and Wiezorek, P.P. 2005. Determination of glyphosate and amino methilphosphoric acid in natural water using the capillary electrophoresis combined with enrichment step. Anal.Chim.Acta 540, 3-7.

[15] Das, B.K and Mukherjee, S.C. 2001. Sublethal effect of quinalphos on selected bood parameters of Labeo rohita (Ham) Fingerlings. Asian fisheries sc. 13:235-238.

[16] Das, P.C., Ayappan, S., Das B.K and Jenas, J.K. 2004. Nitrite toxicity on some selected enzymes in fingerlings of Labeorohitaand Cirrhinosmrigala. Comp. Bioch. Physio. 138:13-18.

[17] Depledge, M.H. 1994. The rational basis for the use of biomarkers as ecotoxicological tools in: Fossi, MC, Leonzio, C (editors). Non destructive biomarkers in vertebrate.Boci Ration Florida: Levis, 271 - 295.

[18] Dhara, V.R., Gassert, H.T. 2004. Acute toxicity of cyanide on common carp, Branchyderio rerio, Current Science 14: $638-641$.

[19] Don, R.N., Simon, Y., Jan, B., Regina K, Keiji.,Baruchi, R., Arata, K., Wemer, K., Michael, L., and John B.U. (2002). Pesticide soil sorption parameters: theory, measurement, uses, limitations and reliability.Pest Manage. Sci, 58(5):419 - 455.

[20] Eddleston, M. (2000). Patterns and problems of deliberate self poisoning in the developing world. O.J. Med. 93:715 - 731 .

[21] Goodman, B.A., Allison, M.J., Oparka, K.J., Hillran J.R. 2006.Xenobiotics: Their activity and motility in plants and soils. Journal of Science, Food and Agriculture, 59:1-20.

[22] Health, A.G. 1995. Water pollution and fish physiology. $2^{\text {nd }}$ ed. Lewis publishes, Bola Raton.

[23] Hontela, A., Daniel C. and Rasmuussen, J.B. 1992. Structural and functional impairment of the hythalamopituta axis in fish exposed to bleached kraft mill effluent in St. Maurice River. Quebec. Ecotoxicology, 6:1 12

[24] Inyang I.R, Gabriel, U.U. and Ogamba E.N. 2010. Sublethal effect of diazinon on selected metabolic parameters of Clarias gariepinus. African journal of Appl. Zoology and environmental biology. 12(1):3236.

[25] Inyang I.R. 2008.Haematological and biochemical responses of Clarias gariepinusto diazinon.PhD Thesis, Rivers State University of Sci and tech. PH.

[26] Inyang, I.R. and Patani, D.E. 2015.Haematological aberrations and electrolyte stabilization in Heterobranchusbidosalisinduced by rhonasate 360SL containing glyphosate.Nigerian Journal of Agriae food and Env. 1(3) 28-31.

[27] Inyang, I.R. and Thomas, S. 2016. Toxicity of fluazifop-p-butyl on blood cells and metabolites of a common African Catfish (Clarias gariepinus) Mg. Journal of Agriculture, Food and environment. 12(2):128 -132.

[28] Inyang, I.R.Adeyemo, A.O, Seiyaboh, E.I and Obele, S.G. 2014. Effect of Kartodem 315EC on some biochemical and metabolic parameters in Clarias gariepinus.BEST Journal, 11(1):159-162.

[29] Jee, L.H., Masroor, F. and Kang, J. 2005. Responses of cypermethrin induced stress in haematological parameters of Koren rockfish, Sebastesschlegeli.Aquaculture Research 36:898 -905.

[30] Jyothi, B and Narayan G. 1999. Certain pesticide induced carbohydrate metabolic disorders in the serum of freshwater fish batrachus (Linn). Food and chemical toxicol. 37:417-421.

[31] Kumar. M.S.P., Trevedi, A.M. and Sharmed, S. 2007. Histopathological changes in testis of the freshwater fish, Heteropreus fossilis (Bloch) exposed to linear alkyl benzene sulphomate. Journal of Envi. Boil. 28.679 -684 .

[32] Martin, B., Stephaine, K., William, W., Kim M.B., Kathy P., Lorriw B., Carol, R., 2003. Childhood pesticide exposures in the Texas-Mexico border: clinical manifestations and poison centre use. A.M. J. public health. 93(8):1310 - 1315.

[33] Masopust, J. 2000. Clinical biochemistry (in zech), karolinum. Praque. 832.

[34] Miller, S.A and Harley J.P. 2004. Zoology. M.C Brown Pub. $2^{\text {nd }}$ ed. 577 -580

[35] Modesto, K.A., Martinez, C.B.R. 2010.Effects of roundup transorb on fish hematology, antioxidant defenses and acetylcholinesterase activity.Chemosphere, 81: $981-787$. 
[36] Ogamba, E.N., Inyang I.R. and Azuma, I.R. 2001. Effect of paraquat dichloride on some metabolic and enzyme parameters of Clarias gariepinus. Current research Journal of biological sciences. $3.156-190$

[37] Ojezele, M.O., Abatan, O.M. 2009. Toxicological effects of chlorpyrifos and methidathion in young chickens. African Journal of biochemistry research 3(3):048 - 051.

[38] Okonkwo, F.O., Ejike, C.F.CC, Anoka, F.N. and Onwurah, I.N and Onwurah, I.N.E. 2013. Toxicological studies on the short term exposure of Clarias albopunctus (Lemonte and Nichole 1927) to sublethal concentrations of roundup Pakistan Journal of biological sciences, 16:939 -944.

[39] Ovuru, S.S.2004. Gonodal and physiological responses of rabbit exposed to crude oil contaminated feed. Ph.D Thesis. Dept. of animal sc, Rivers State University of Sc. \& tech. Port Harcourt.

[40] Oyoroko, E. and Ogamba, E.N. 2017.Effect of detergent containing linear alkyl benzene sulphonate on behavioural response of Heterobranchusbidorsalis, Clarias gariepinusandHeteroclarias. Biotechnol. Res. 3(3):59-64.

[41] Semante, P., Pal, S.,Murkherjee A and Ghosh, A. 2014. Evaluation of metabolic enzymes in response to excel mera 71, a glyphosate based herbicide and recovery pattern in freshwater teleostean fishes. Biomed research International. 1419 - 425

[42] Svoboda, M, Luskova, V., Drastichora, J, and Zlabek, V. 2001. Effect of diazinon on haematological indices of common carp Cyprinuscarpio) Acta, Vet Brno 70:457 - 465.

[43] Taylor, D.J., Green, N.PO and Stout, G.W., 2005. Biological Science. Cambridge Univ. press. $3^{\text {rd }}$ ed., 459 $-463$.

[44] Tu, M., Hurd, C., and Randal, M.J. 2001. Weed control methods handbook, the nature conservancy. http//www.invasive.org/gist/handbook.html. Accessed 2015.

[45] Vitek, L and Ostrou, J.D. 2009. Bilirubin chemistry and metabolism, harmful and protective aspects. Curr. Pharm. Design. 15:2869 - 2883.

[46] Wahua TAT (1999) Applied statistics for scientific studies. Africa link books, Ibadan, Nigeria.

[47] Yekeen, T.A and Fawole, O.O. 2011.Toxic effects of endosulfan on haematological and biochemical indices of Clarias gariepinus. African Journal of Biotechnology, 10(64):90-96.

Citation: Inyang, I.R., et al,, " Evaluation of Some Blood Cells and Metabolites of Heterobranchus Bidorsalis (Hybrid) Exposed to Sublethal Concentrations of Sarosate", International Journal of Research in Environmental Science (IJRES), vol. 5, no. 1, pp. 17-23, 2019. Available: DOI: http://dx.doi.org/10.20431/2454-9444.0501004

Copyright: () 2019 Authors. This is an open-access article distributed under the terms of the Creative Commons Attribution License, which permits unrestricted use, distribution, and reproduction in any medium, provided the original author and source are credited. 